\title{
Sprawozdanie z czwartej edycji programu Indonesian Interfaith Scholarship 2017, Dżakarta - Semarang - Dżokdżakarta - Bali 24-30 lipca 2017 r.
}

W lipcu 2017 r., ambasada Republiki Indonezji w Brukseli we współpracy z Ministerstwem do Spraw Religijnych i Ministerstwem Spraw Zagranicznych Indonezji, zorganizowala czwartą edycję programu Indonesian Interfaith Scholarship (IIS 2017). Tegoroczna edycja programu skierowana była do trzech grup osób. Pierwszą grupę uczestników stanowili przedstawiciele Parlamentu Europejskiego, odpowiedzialni za przygotowywanie ekspertyz z zakresu stosunków międzynarodowych, a także współpracujący z poszczególnymi europosłami z Estonii, Niderlandów, Rumunii i Węgier. Druga grupa uczestników skupiała ekspertów studiów azjatyckich, reprezentujacych europejskie think-tanki. Trzecia grupę uczestników tworzyli przedstawiciele środowisk uniwersyteckich. Łącznie, w czwartej edycji programu udzial wzięlo dziewięć osób zaproszonych przez Stale Przedstawicielstwo Republiki Indonezji przy Unii Europejskiej.

Program, którego pierwszą edycję zorganizowano w 2013 r., skierowany jest na ukazanie zasad i praktycznego funkcjonowania społeczeństwa opartego na zasadzie harmonii religijnej i pokojowego wspólistnienia wyznawców sześciu oficjalnych religii Indonezji, tj. islamu, protestantyzmu, katolicyzmu, hinduizmu, buddyzmu i konfucjanizmu. Sześć systemów religijnych, uznanych oficjalnie za religie Indonezji, stanowi integralną część zarówno spoleczeństwa indonezyjskiego, jak i życia politycznego państwa. Trwający siedem dni program umożliwil kontakt z przedstawicielami Ministerstwa do spraw Religijnych Republiki Indonezji, Ministerstwa Spraw Zagranicznych, Parlamentu Republiki Indonezji, ale przede wszy stkim z reprezentantami środowisk religijnych, w szczególności z przedstawicielami islamskich szkół religijnych, państwowych uniwersytetów islamskich, seminarium katolickiego, a także Kościoła katolickiego w Indonezji, Kościoła protestanckiego w Indonezji oraz z reprezentantami społeczności buddyjskiej i wyznania hinduistycznego.

Pierwszego dnia uczestnicy programu IIS 2017 spotkali się z przedstawicielami Ministerstwa do spraw Religijnych i Centrum ds. Harmonii Religijnej, którzy zwrócili uwagę na podstawowy problem związany z pokojowym współistnieniem wyznawców różnych religii $w$ Indonezji. Państwo unitarne, zlożone z 34 prowincji i 500 dystryktów, polożone na 17504 wyspach, obejmujacce trzy strefy czasowe, ma ponad 255 milionów mieszkańców (wedlug spisu powszechnego z 2016 r.), tworzących jedno spoleczeństwo, lecz należących do 1340 grup etnicznych, posługujących się ponad 100 językami i wyznających ponad 20 religii, z których sześć uznanych zostało za oficjalne religie państwowe. W tak zróżnicowanym spoleczeństwie osiagnięcie pokojowego współistnienia jest niezbędne dla zachowania jedności państwa, zarówno w sferze funkcjonowania wewnętrznego, jak i na arenie międzynarodowej. Cel ten realizowany jest w oparciu o zasadę Pancza Szila ${ }^{1}$,

${ }^{1}$ Nie mylić z zasadą Pancza Szila, będącą podstawą funkcjonowania Ruchu Państw Niezaangażowanych. 
w myśl której istotą funkcjonowania Indonezji jest: 1) wiara w jednego boga; 2) unitarny charakter państwa; 3) sprawiedliwe i cywilizowane spoleczeństwo; 4) demokracja oparta na mądrości i dążeniu do osiagnięcia konsensusu; 5) sprawiedliwość spoleczna i dobrobyt $^{2}$. Zasada Pancza Szila znajduje odzwierciedlenie w Konstytucji Republiki Indonezji z 1945 r. (z późniejszymi zmianami, wprowadzonymi w następstwie reform politycznych w 1998 r.). Konstytucja zobowiązuje władze państwa do ochrony zarówno sześciu oficjalnych religii, jak i ich wyznawców. Gwarantuje wolność wyznania, wskazując w szczególności na wolność wyboru wyznania i wolność praktyk religijnych (artykul 28$)^{3}$. W efekcie, sposobem zachowania jedności państwa i spoleczeństwa, porządku wewnętrznego i pokojowego wspólistnienia jest edukacja religijna (obowiązkowa na poziomie edukacji podstawowej i średniej), edukacja kulturowa oraz dialog międzywyznaniowy, realizowany przez organizacje pozarzadowe, spoleczności lokalne oraz strategie i programy rządowe, a także działalność Narodowej Rady Religijnej, skupiającej przedstawicieli sześciu oficjalnych religii Indonezji.

Kwestie te zostały poruszone również podczas spotkania z przedstawicielami Ministerstwa Spraw Zagranicznych Indonezji oraz w czasie rozmów z Charlesem-Michelem Geurtsem w Przedstawicielstwie Unii Europejskiej w Indonezji. Wskazano na dlugowiekowa tradycję tolerancji religijnej i wspótistnienia wyznawców różnych systemów religijnych w Indonezji. Zwrócono jednak uwagę na ostatnie wydarzenia, które w watpliwość podają stabilność systemu Pancza Szila. W szczególności podkreślono kontrowersje związane ze sprawą bylego gubernatora Dżakary, Basuki Tjahaja Purnama, znanego jako Ahok, ze wzrostem popularności ugrupowań radykalnych, a także z aktywnością legislacyjną państwa, która budzi uzasadnione obawy przedstawicieli organizacji zajmujacych się ochroną praw czlowieka. Chodzi zwlaszcza o proponowane zmiany do ustawy o ochronie praw religijnych ${ }^{4}$.

Drugi dzień poświęcono na spotkania z przedstawicielami środowiska muzulmańskiego (meczet Niepodleglości Istiqlal) i katolickiego (Katedra pod wezwaniem Wniebowzięcia NMP) w Dżakarcie oraz z reprezentantami partii obecnych w Parlamencie Republiki Indonezji. Zgodnie z ideą programu IIS 2017, celem było ukazanie harmonii religijnej, tj. dialogu i wspólpracy między wyznaniami. Tymczasem spotkania w meczecie i katedrze pokazaly pokojowe, lecz chłodne wspólistnienie, a nie rzeczywisty dialog i wspólpracę. Sam fakt, że zorganizowano dwa odrębne spotkania, uwidocznil brak dialogu i rzeczywi-

${ }^{2}$ Preambula, The State Constitution 1945 of the Republic of Indonesia, w: Compendium Regulations Inter-Religious Harmony, Center for Inter-Religious Harmony. Secretariat General, Ministry of Religious Affairs of the Republic of Indonesia, Jakarta 2016, s. 13.

${ }^{3}$ Warto jednak zwrócić uwagę na zawężoną interpretację tego uprawnienia. Po pierwsze, nie daje ono prawa do odrzucenia systemu religijnego i pozostania osobą niewierzaca. Formalnie, państwo wymaga od każdego obywatela dokonania wyboru i wskazania jednego z sześciu oficjalnych wyznań. Po drugie, wolność wyznania, wyboru wyznania i praktyk religijnych odnosi się jedynie do sześciu oficjalnych wyznań. W konsekwencji, wyznawcy religii i wierzeń innych niż oficjalnie uznane oraz osoby niewierzace, napotykaja problemy w realizacji praw obywatelskich i politycznych. Dla przykładu: 1) związek małżeński mogą zawrzeć jedynie wyznawcy religii oficjalnie uznanych; 2) w przypadku, gdy małżeństwo mają zawrzeć wyznawcy różnych religii, od jednej z osób wymagana jest konwersja; 3 ) rejestracja narodzonego dziecka wymaga wskazania jego wyznania i nie nastapi w przypadku religii innych niż sześć oficjalnie uznanych.

${ }_{4} 21$ lipca 2017 r., na trzy dni przed rozpoczęciem programu IIS 2017, Ministerstwo ds. Religijnych Republiki Indonezji przedstawilo projekt zmian do ustawy o ochronie praw religijnych, zaostrzajacych kary za bluźnierstwo od sześciu miesięcy do pięciu lat pozbawienia wolności. 
stej kooperacji. W odpowiedzi na pytanie o przyklady dialogu między islamem i katolicyzmem, ograniczono się do wskazania wzajemnego użyczania parkingów podczas wielkich świąt religijnych - muzułmańskich i katolickich - tak, aby wyznawcy mogli swobodnie uczestniczyć w nabożeństwach. Podczas spotkania w parlamencie, zwrócono uwagę na miejsce religii w życiu politycznym państwa, które z chwilą uzyskania niepodległości w 1945 r. odrzucilo zarówno model państwa teokratycznego, jak i państwa świeckiego, opierając funkcjonowanie na religijnym charakterze z jednoczesnym uznaniem sześciu systemów religijnych (i filozoficznych). Podkreślono skomplikowane uwarunkowania realizacji idei harmonii religijnej, zwrócono uwagę na istniejące problemy i wątpliwości wysuwane przez przedstawicieli Unii Europejskiej czy organizacji zajmujacych się ochrona praw czlowieka.

Trzeci dzień programu, realizowany w Semarang, objąl spotkania z przedstawicielami muzułmańskiej większości, reprezentowanej przez przedstawicieli Państwowego Islamskiego Uniwersytetu Walisongo. W trakcie dyskusji podkreślono dwie kluczowe kwestie. Pierwsza jest znaczenie dialogu i dyskusji w rozwiązywaniu sporów i ewentualnych konfliktów religijnych w społeczności lokalnej, czego przykladem jest prowadzone przez uczelnię centrum mediacji. Kwestia druga to indonezyjski charakter islamu, oparty na multikulturowości, adaptacji tradycji i wierzeń lokalnych spoleczności, a nawet elementów charakterystycznych dla pozostalych systemów religijnych. Przykładem może być częsty brak kopuł na meczetach (zastapionych przez czworokątne dachy), siedmiodniowe opłakiwanie zmarlych (przejęte z buddyzmu) czy użycie bębna, zwanego bedug (wywodzącego się z kultury chińskiej $\mathrm{i}$ indyjskiej) jako sygnału wzywającego na modlitwę.

Kolejny dzień programu IIS 2017 poświęcono na spotkania z przedstawicielami środowiska buddyjskiego w Dżokdżakarcie. Kluczowe miejsce w rozmowach poświęcono historii obecności wyznawców buddyzmu w Indonezji oraz współpracy z przedstawicielami islamu. Holland C. Taylor, emisariusz organizacji Gerakan Pemuda Ansor ${ }^{5}$ w Organizacji Narodów Zjednoczonych, na kontynentach amerykańskich i w Europie, podkreślił wagę przyjętej w maju 2017 r. Deklaracji w sprawie Humanitarnego Islamu, dla dialogu religijnego. Uzgodniona mapa drogowa reformy ortodoksyjnego islamu obejmuje pięć etapów działań, tj. identyfikację zagrożeń; rozwiązywanie konfliktów; nowy dyskurs teologiczny skierowany na dostosowanie islamu do wspólczesności; przyjęcie i rozwój nowych programów nauczania w świecie islamskim; oddolna kampania na rzecz budowy spolecznego konsensusu ${ }^{6}$. Istniejące wyzwania zobrazowało spotkanie z pracownikami islamskiej szkoly Pesantren Ali Maksum w Krapyak, którzy odwolywali się do idei tolerancji i dialogu między wyznawcami sześciu oficjalnych religii Indonezji, lecz przykładów rzeczywistej wspólpracy między wyznaniami podać nie umieli. Przejawem tolerancji i dialogu prowadzonego przez szkołę jest - ich zdaniem - nowoczesne nauczanie islamu, dalekie od radykalizmu i uznania wiodacej roli tej religii.

Niezwykle interesującą dyskusję podjęto kolejnego dnia na Uniwersytecie Sunan Kalijaga. Starannie przygotowane prezentacje pracowników naukowych uniwersytetu spotkały się z dużym zainteresowaniem uczestników programu IIS 2017. Dyskusję skierowano na zobrazowanie zasadniczych różnic między islamem propagowanym w regionie Bliskiego Wschodu a islamem w rozumieniu indonezyjskim, odzwierciedlającym zarówno

${ }^{5}$ Największa na świecie islamska organizacja młodzieży.

6 Por. Ansor Declaration on Humanitarian Islam, 22 May 2017, http://www.baytarrahmah.org/ media/2017/Gerakan-Pemuda-Ansor_Declaration-on-Humanitarian-Islam.pdf (3.08.2017). 
ideę ochrony praw czlowieka, jak i podkreślającym równouprawnienie i istotną rolę kobiet w społeczeństwie. Spotkanie na Uniwersytecie Sunan Kalijaga pokazało nowoczesny, umiarkowany charakter islamu indonezyjskiego, uznającego istnienie innych systemów religijnych.

Ostatnie dwa dni programu IIS 2017 realizowano na Bali, kierując uwagę przede wszystkim na wspólistnienie wyznawców hinduizmu (stanowiących większość na wyspie) z przedstawicielami pozostalych oficjalnych religii Indonezji. W odróżnieniu od wcześniejszych spotkań, na Bali ukazano rzeczywistą wspólpracę i dialog międzyreligijny, zapraszając do uczestnictwa $w$ dyskusjach jednocześnie przedstawicieli różnych wyznań. W rozmowach wskazano wspólne inicjatywy i daleko rozwinięta kooperację. Otwarcie przyznano, że wspólpraca i dialog - niezbędne dla zapewnienia pokojowego wspólistnienia wyznawców różnych religii - gwarantują stabilizację sytuacji wewnętrznej na Bali', a tym samym rozwój turystyki i gospodarki.

Program Indonesian Interfaith Scholarship uznać należy za niezwykle cenną inicjatywę władz Indonezji, które odpowiadając na krytykę działań podejmowanych po $1998 \mathrm{r}$. względem mniejszości religijnych oraz na przypadki zamachów terrorystycznych dokonywanych przez fundamentalistów islamskich (w Dżakarcie w 2016 r. i na Bali w 2002 i 2005 r.), dążą do ukazania państwa wieloreligijnego, funkcjonującego w oparciu o tolerancję i dialog. Choć promowanie umiarkowanego islamu - stanowiacego religię wiodaca - jest niezwykle istotnym elementem harmonii religijnej w Indonezji, to pozostaje mieć nadzieję, że harmonia religijna nie ograniczy się jedynie do "chlodnego" wspólistnienia sześciu religii oficjalnych, lecz do rzeczywistej wspólpracy ich przedstawicieli i wyznawców, a także do prawnego uregulowania sytuacji wyznawców religii nieoficjalnych.

\section{Indonesian Interfaith Scholarship 2017, Jakarta - Semarang - Yokyakarta - Bali 24-30 July 2017}

In July 2017, Embassy of the Republic of Indonesia in cooperation with the Ministry of Religious Affairs and Ministry of International Affairs, organized the fourth edition of the Indonesian Interfaith Scholarship (IIS 2017), attended by nine participants.

The program, initiated in 2003, is aimed at presentation of principles and functioning of a society based on religious harmony and peaceful coexistence of six official religions. These are: Islam, Protestantism, Catholicism, Hinduism, Buddhism, and Confucianism. These six religious systems, recognized officially, are integral part of Indonesian society and Indonesian political life. The IIS program made it possible to contact representatives of the Ministry of Religious Affairs, Ministry of International Affairs, Parliament of the Republic, but above all with representatives of religious groups, especially Islamic boarding schools, Catholic seminars, Islamic state universities, representatives of Hindu and Buddhist communities.

During first day of IIS 2017 participants met representatives of the Ministry of Religious Affairs and Centre for Religious Harmony, who paid attention on the basic problem for peaceful coexistence of different religions in Indonesia. The unitary state, composed of

\footnotetext{
${ }^{7}$ Szczególnie po zamachach terrorystycznych w 2002 i 2005 r.
} 
34 provinces and 500 districts, located on 17504 islands, comprising three time zones, has over $255,000,000$ inhabitants (according to the 2016 census) being one society, but belonging to 1340 ethnic groups, speaking more than 100 languages and professing more than 20 religions. In such a diverse society, peaceful coexistence is necessary to preserve the state unity, both in internal and external arena. This aim is implemented through the Pancasila principles, namely: (1) belief in one God; (2) unitary character of the state; (3) just and civilized society; (4) democracy "led by wisdom" of consensus; (5) social justice for all members of society. ${ }^{1}$ The principles are guaranteed in the Indonesian Constitution of 1945 (with later amendments). The Constitution obliges authorities to protect six official religions as well as their believers. It guarantees freedom of religion, especially "freedom to embrace a religion and to worship" (Art. 28). ${ }^{2}$

In order to achieve the unity of Indonesia and its society, as well as the internal order and peaceful coexistence, Indonesian authorities apply obligatory religious education, cultural education and interfaith dialogue, implemented by non-governmental organizations, local communities, as well as through governmental strategies and programs and activities of National Board composed of six official religions representatives. Such a complex system, based upon governmental (central and local) and non-governmental elements, must be appreciated and regarded as a guarantee for peaceful coexistence of different religions.

These issues have been tackled during a meeting with representatives of the Ministry of Foreign Affairs and during a discussion with Charles-Michel Geurts in the EU Delegation to Indonesia. On one hand, Indonesian tradition of religious tolerance and coexistence has been pointed. On the other, incidents of religious intolerance, as well as some problematic tendencies have been stressed. The EU concerns are connected with: (1) the case of Basuki Tjahaja Purnama (Ahok); (2) growth of support for radical groups; (3) legislation activities, criticized by human rights organizations. Although the Ahok case cannot be treated as a threat for the religious harmony concept, legislation changes can be regarded as contrary to human rights guarantees, especially to freedom of religion. On 21 July 2017, three days before IIS 2017 started, the Ministry of Religious Affairs presented a draft religious rights protection bill, which expands the scope of Act No. 1/PNPS/1965 on the Prevention of Religious Abuse and/or Blasphemy. If it is approved by the Parliament, it will make possible to impose more restrictive imprisonment sanctions for blasphemy (from six months to five years).

The second day of IIJ 2017 was planned for meetings with Muslim (the Istiqlal Mosque) and Catholic (the St. Mary of the Assumption Cathedral) representatives, as well as representatives of political parties present in the Indonesian Parliament. According to

Preambule, The State Constitution 1945 of the Republic of Indonesia, in: Compendium Regulations Inter-Religious Harmony, Center for Inter-Religious Harmony. Secretariat General, Ministry of Religious Affairs of the Republic of Indonesia, Jakarta 2016, p. 13.

2 It is necessary to stress the limited interpretation of this freedom. First, it does not give a right to reject all religious systems and be a non-believer. Formally, the state demands every citizen to choose and indicate one of six official religions. Secondly, freedom of religion is connected only with six official religions of Indonesia. Consequently, believers of religions other than six official ones, have problems to use their civil and political rights. For example: (1) a marriage can only be contracted by followers of six religions recognized by the state; (2) in case of a marriage to be contracted between members of two officially recognized religions, one must convert; (3) a new born baby will be registered only after his/her religion in indicated. These provisions question the idea of religious harmony in Indonesia as they lead to social and political exclusion of some citizens. 
the main idea of IIS 2017, the aim was to show religious harmony, namely dialogue and cooperation among different religions. Meanwhile, the meetings in the Mosque and the Cathedral, presented peaceful, but cold coexistence, not a real dialogue and cooperation. The fact that there were two separate meetings is an evidence of lack of dialogue and real cooperation. Answering a question concerning examples of dialogue between Islam and Catholicism, representatives of both religions mentioned mutual parking lending, making it possible for followers to take part in devotions. During a meeting in the Parliament, attention was paid to the concept of ties between a state and religion. It has been stressed that in 1945 when Indonesia declared independence, the idea of a theocratic stated has been rejected, together with the idea of a secular state. Instead, a decision that Indonesia would be a state respecting six religions has been made. Complex and complicated conditions for religious harmony have been underlined, existing problems and doubts of EU and human rights organizations have been discussed.

The third day of the program was realized in Semarang. During a meeting with $\mathrm{Mu}-$ slim majority, represented by academic teachers of the State Islamic University in Walisongo, two crucial issues have been pointed. The first is the importance of dialogue and discussion disputes or conflicts resolution in local communities. The example is a mediation center run by the University. The second issue is the Indonesian character of Islam, based on multiculturalism and adaptation of local traditions and beliefs. The example can be a bedug drum signaling time for a prayer in mosques or a seven-day mourning for the dead. The meeting at the University was one of the most crucial to understand the character of Indonesian Islam - the religion of majority implementing elements of minority religions.

The next day of IIS 2017 made it possible to meet representatives of Buddhist community in Indonesia, in Yokyakarta. The key issue discussed was history of Buddhist presence in Indonesia and cooperation with Islamic community. Holland C. Taylor from LibForAll Foundation and emissary of Gerakan Pemuda Ansor ${ }^{3}$ to the United Nations, Americas and Europe, was talking about the Ansor Declaration on Humanitarian Islam, adopted in May 2017 and its importance for religious dialogue. A detailed road map on religious dialogue focuses on: (1) identification of threats; (2) conflict resolution; (3) new theological discourse to recontextualize Islamic teachings for modern era; (4) development and adoption of new curricula in Islamic world; (5) grassroot movement to build societal consensus and resolve possible crises. ${ }^{4}$ Existing challenges were visible during a meeting with teachers from Islamic school Pesantren Ali Maksum in Krapyak. They were talking about tolerance and dialogue among followers of six official religions but could not give real examples of such a dialogue. Manifestation of tolerance and dialogue in school activities are - in their opinion - modern Islamic teachings, far from radicalism.

Extremely interesting discussion took place the next day at the Sunan Kalijaga University. Academic presentations illustrated main differences between Islam in the Middle East and Islam in Indonesia - the second focusing on human rights protection, women equality and their crucial role in society. The meeting at the Sunan Kalijaga University showed modern, moderate character of Indonesian Islam, recognizing and accepting other religions.

3 The biggest Islamic youth organization in the world

4 See: Ansor Declaration on Humanitarian Islam, 22 May 2017, http://www.baytarrahmah.org/ media/2017/Gerakan-Pemuda-Ansor_Declaration-on-Humanitarian-Islam.pdf (3.08.2017). 
The last two days of IIS 2017 took place in Bali, and focused mostly on Hindu community, being a majority religion in the island. In contrast to previous meetings, in Bali a real cooperation and inter-religious dialogue have been showed. In discussions, representatives of different religions took part hand in hand, taking about daily cooperation and common initiatives. They openly admitted that cooperation and dialogue - necessary to ensure peaceful coexistence of different religions and their followers - guarantee internal stabilization in Bali, ${ }^{5}$ and consequently: development of tourism and economy.

The Indonesian Interfaith Scholarship must be regarded as an extremely important and valuable initiative of Indonesian authorities, responding to an international critique of activities taken after 1998 with respect to religious minorities and to terrorist attacks run by Islamic fundamentalists (in Jakarta in 2016, in Bali in 2002 and 2005). The aim of the program is to show Indonesia as a multi-religious state, functioning upon tolerance and dialogue. Promotion of moderate Islam - being the majority religion - is the key element of religious harmony in Indonesia. However, religious harmony in Indonesia cannot be limited only to "cold" coexistence of six official religions, and must be about trust and real cooperation of religious representatives and followers.

Anna POTYRAŁA

Poznań

${ }_{5}^{5}$ Especially after terrorist attacks in 2002 and 2005. 